\title{
Research Article \\ Activity Prediction of Bioactive Compounds Contained in Etlingera elatior Against the SARS-CoV-2 Main Protease: An In Silico Approach
}

\author{
Dwi Syah Fitra Ramadhan ${ }^{*}$ \\ Taufik Muhammad Fakih 2 \\ Arfan 3 \\ 1Department of Pharmacy, Universitas \\ Mandala Waluya, Kendari, South East \\ Sulawesi, Indonesia \\ 2Department of Pharmacy, Universitas \\ Islam Bandung, Bandung, West Java, \\ Indonesia \\ 3Department of Pharmacy, Universitas \\ Halu Oleo, Kendari, South East \\ Sulawesi, Indonesia \\ *email: ditrakdi@gmail.com \\ Keywords: \\ COVID-19 \\ Etlingera elatior \\ In silico \\ Main protease
}

\begin{abstract}
The COVID-19 pandemic has become a serious problem today, with its prevalence increasing every day. The SARS-CoV-2 main protease $\left(\mathrm{M}^{\mathrm{Pro}}\right)$ is a promising therapeutic target to inhibit replicating and spreading the virus that causes COVID-19. The compounds contained in the Etlingera elatior plant has the potential. This study aimed to examine the compounds' activity in E. elatior against SARS-CoV-2 MPro using in silico methods. A total of seven compounds contained in E. elatior were obtained from the Knapsack database. The compounds were then docked into the SARS-CoV-2 MPro receptor's active site with the PDB ID 6LU7. Afterward, the biological activities were predicted by the PASS prediction webserver. The molecular docking results showed that ergosterol peroxide and sitostenone had the best binding energy with $-10.40 \mathrm{kcal} / \mathrm{mol}$ and $-9.17 \mathrm{kcal} / \mathrm{mol}$, respectively. The in silico PASS prediction showed it has potential as antiviral therapy. It concluded ergosterol peroxide and sitostenone has the potential as SARS-CoV-2 MPro inhibitor candidate.
\end{abstract}

Received: August 30th, 2020

Accepted: October $24^{\text {th }}, 2020$

Published: November 30th, 2020

(c) 2020 Dwi Syah Fitra Ramadhan, Taufik Muhammad Fakih, Arfan. Published by Institute for Research and Community Services Universitas Muhammadiyah Palangkaraya. This is an Open Access article under the CC-BYSA License (http://creativecommons.org/licenses/by-sa/4.0/). DOI: https://doi.org/10.33084/bjop.v3i4.1634

\section{INTRODUCTION}

Coronavirus disease 2019 (COVID-19) is a disease caused by infection with the SARS-CoV-2 virus, which in January 2020 began to spread from Wuhan around the world (Hui et al., 2020). Globally, on August 30 th 2020, there have been 24,854,140 confirmed cases of COVID-19, including 838,924 deaths (World Health Organization, 2020). One of the targets that have become a focus of research in the world for COVID-19 therapy was SARSCoV-2 main protease (M ${ }^{\text {Pro }}$ (Dai et al., 2020; Jin et al., 2020; Wu et al., 2020; Zhu et al., 2011). The main protease is a key enzyme in the viral replication cycle, which proteolytically cleaves overlapping polyproteins pp1a and pplab into functional proteins, an essential step during viral replication (Du et al., 2004). Inhibition of these target proteins can result in disruption of the SARS-CoV2 replication cycle (Mahmud et al., 2020; Pratama et al., 2020). The SARS-CoV-2 M $M^{\text {Pro }}$ in COVID-19 is not the same as the main protease in humans, so it becomes a promising therapeutic target (Ullrich \& Nitsche, 2020).

Many compounds derived from medicinal plants have not been discovered and have great potential as therapeutic candidates (Mushtaq et al., 2018; Pan et al., 2013). In the discovery of COVID-19 therapy candidates, many natural products were used; some of them examined compounds from herbs against the SARSCoV-2 using in silico method (Aanouz et al., 2020; Enmozhi et al., 2020; Joshi et al., 2020; Prasanth et al., 2020; Sukardiman et al., 2020). However, the discovery of 
compounds from medicinal plants with potential activity

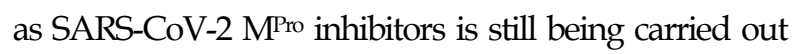
today.

Etlingera elatior (known as Wualae in Tolakinese) is a medicinal plant from Indonesia which are found mainly on the island of Sulawesi, particularly Southeast Sulawesi (Fristiohady et al., 2020; Fristiohady et al., 2019). Etlingera elatior contains various types of compounds, including flavonoids and steroids with various pharmacological activities, one of them as antimicrobial (Sahidin et al., 2019; Wahyuni et al., 2018). However, there has been no specific development of its antiviral activity until now, especially to the SARS virus family. Flavonoid and steroid group compounds as found in E. elatior have been widely researched on their activity to the SARS-CoV-2 and have shown promising results as a drug candidate for COVID-19 (Islamet al., 2020; Suwannarach etal., 2020). Therefore, this study aims to identify compounds from the flavonoid and steroid group contained in E. elatior, which have potential as SARS-CoV-2 $\mathrm{M}^{\text {Pro }}$ inhibitors.

\section{MATERIALS AND METHODS}

\section{Ligand preparation}

The ligands used in this study were compounds contained in E. elatior. A total of seven compounds contained in E. elatior were selected in this study based on the KNApSAcK database (http://www.knapsackfamily.com/KNApSAcK/)

(Afendi et al., 2012). The compound identity, as well as their two-dimensional structure, can be seen in Table I. The three-dimensional ligand conformation was obtained from the KNApSAcK 3D database (http://knapsack3d.sakura.ne.jp/) (Nakamura et al., 2013). The compounds saved in .mol format, then converted into .pdb format using the OpenBabel 2.4.1 GUI software.
Table I. Identity of the compounds contained in E. elatior based on the KNApSAcK database

C_ID
KNApSAcK Compounds

\section{Receptor preparation}

The three-dimensional structure of the SARS-CoV-2 $\mathrm{M}^{\text {Pro }}$ was obtained from the Protein Data Bank (PDB) website http:/ / www.rcsb.org/pdb/. The receptor with the PDB ID 6LU7 and resolution $2.16 \AA$ was chosen. Furthermore, the unique ligands and water molecules were removed from the receptor. Then, the receptor was added with polar hydrogen and given a charge (Kollman charge). All preparation procedures were performed using AutoDock 4 software (Morris et al., 2009).

\section{Validation method}

The native ligand from the 6LU7 receptor ( $\mathrm{N}-[(5-$ methylisoxazol-3-yl)carbonyl]alanyl-1-valyl-N 1 ((1R,2Z)-4-(benzyloxy)-4-oxo-1-\{[(3R)-2-oxopyrrolidin-3yl]methyl\}but-2-enyl)-1-leucinamide; an inhibitor N3) (Jin et al., 2020) was separated from the protein, then redocked using AutoDock 4 software into the previous active site. The native ligand conformation from the 
docking procedure was taken and overlayed with the native ligand conformation before docking. Furthermore, validation is done by looking at root-meansquare deviation (RMSD) parameters, calculated using PyMOL software. An RMSD value of fewer than $2.0 \AA$ indicates that the method is valid and can be used for the docking process (Bell \& Zhang, 2019).

\section{Molecular docking simulation}

The simulation was carried out using previously valid parameters. The three-dimensional structure of the compounds in E. elatior was docked to the SARS-CoV-2 $\mathrm{M}^{\mathrm{Pro}}$ receptor's active site, which is then analyzed for its binding energy and amino acid interactions. The active site coordinates were $x=-9.732, y=11.403$, and $z=68.925$, with the dimensions of the grid box, were 64,60 , and 60 $\AA$, respectively. The docking process in AutoDock 4 has been performed with 100 number of GA runs for each ligand.

\section{Prediction of Activity Spectra for Substances}

The in silico Prediction of Activity Spectra for Substances (PASS) were carried out to get biological activity spectra of compounds accessed through PASS web server (http://www.way2drug.com/PASSOnline/predict.ph p) (Marwaha et al., 2007). This server estimates the predicted activity spectrum of a compound as probable activity $(\mathrm{Pa})$ and probable inactivity $(\mathrm{Pi})$. Prediction of this spectrum by PASS is based on structure-activity relationship analysis of the training set containing more than 205,000 compounds exhibiting more than 3,750 kinds of biological activities. For probabilities range, the $\mathrm{Pa}$ and Pi values vary from 0.000 to 1.000 . The PASS prediction results were interpreted and used flexibly:

1. Only activities with $\mathrm{Pa}>\mathrm{Pi}$ are considered as possible for a particular compound.

2. If $\mathrm{Pa}>0.7$, the chance to find activity is experimentally high.
3. If $\mathrm{Pa}$ is $>0.5$ but less than $<0.7$, the chance to find activity is experimentally low, but the compound is probably different from known pharmaceutical agents.

4. If $\mathrm{Pa}<0.5$, the chance to find activity is experimentally is low, but the chance to find structurally NCE's is high.

\section{RESULTS AND DISCUSSION}

\section{Validation method}

Validation was carried out to see the strength of affinity prediction through re-docking the native ligand into its binding site. The validation results can be seen in Figure 1. It showed that the RMSD value of the native ligand was $1.3 \AA$, with the binding energy obtained was -7.30 $\mathrm{kcal} / \mathrm{mol}$. This shows that the molecular docking method used is valid because of the RMSD value below $2.0 \AA ̊$.

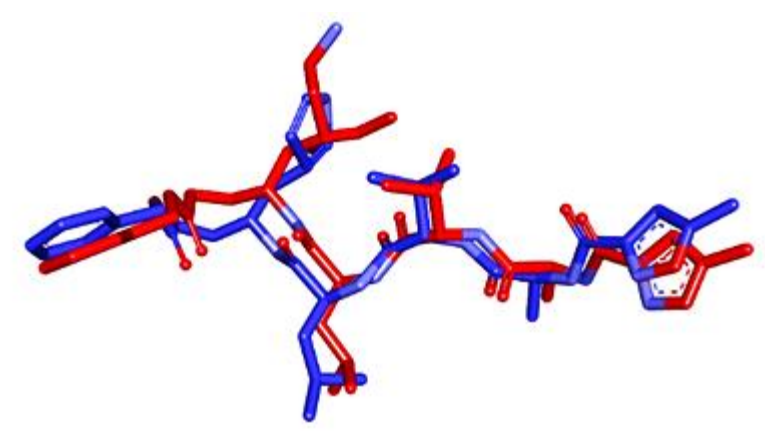

Figure 1. Validation of the SARS-CoV-2 $M^{\text {Pro }}$ receptor PDB ID 6LU7, the native ligand position before docked (red) and after docked (blue) overlayed with RMSD $1.3 \AA$

\section{Molecular docking simulation}

The bioactive compounds in E. elatior after docked showed varied binding energies as shown in Table II. In general, E. elatior compounds from the database were dominated by polyphenols such as flavonoids and phenylpropanoid, then the steroid compounds. The flavonoid compounds such as quercetin, curcumin, etc., have been previously studied in silico against the SARSCoV-2 Mro receptor, as Cherrak et al. (2020) reported. 
Meanwhile, the type of steroid has been previously studied by Ghosh et al. (2020). As shown by the docking results in Table II, the steroid group showed better inhibitory activity than the flavonoid groups to SARS$\mathrm{CoV}-2 \mathrm{M}^{\mathrm{Pro}}$ receptor. The docking results show that the steroids' binding energy, namely ergosterol peroxide and sitostenone, was -10.4 and $-9.17 \mathrm{kcal} / \mathrm{mol}$, respectively. Compared to the flavonoid group, the lowest binding energy was shown by catechins $(-8.64 \mathrm{kcal} / \mathrm{mol})$, while the binding energy of the other compounds was in the range of -6.53 to $-7.9 \mathrm{kcal} / \mathrm{mol}$.

Table II. The binding energy of the compounds in E. elatior to the SARS-CoV-2 $\mathrm{M}^{\text {Pro }}$ receptor

\begin{tabular}{llrr}
\hline \multicolumn{1}{c}{ Compounds } & $\begin{array}{c}\text { Compound } \\
\text { group }\end{array}$ & $\begin{array}{c}\text { Binding } \\
\text { energy } \\
\text { (kcal/mol) }\end{array}$ & \multicolumn{1}{c}{$\begin{array}{c}\text { Ki } \\
(\mathbf{n M})\end{array}$} \\
\hline Catechins & $\begin{array}{l}\text { Flavonoid } \\
\text { Chlorogenic acid }\end{array}$ & -8.64 & 467,520 \\
& $\begin{array}{l}\text { Phenyl- } \\
\text { propanoid }\end{array}$ & -6.53 & 16,380 \\
Kaempferol 3- & Flavonoid & -7.08 & 6,450 \\
glucuronide & & & \\
Isoquercetin & Flavonoid & -7.09 & 6,310 \\
Sitostenone & Steroid & -9.17 & 188.59 \\
Ergosterol peroxide & Steroid & -10.4 & 23.62 \\
Demethoxycurcumin & Polifenol & -7.9 & 1,630 \\
\hline
\end{tabular}

\section{Molecular interactions}

The top two compounds that ranked by their binding energy, ergosterol peroxide and sitostenone, were analyzed for their amino acid interactions with theSARS$\mathrm{CoV}-2 \mathrm{M}^{\mathrm{Pro}}$ receptor and compared with the interactions of the native co-crystal ligand (N3 inhibitor). The interactions' tabulation data can be seen in Table III, while the two-dimensional interaction can be seen in Figure 2. The native ligand forms hydrogen bonds with amino acids Gly-143; Cys-145; Glu-166; Gln-189; and Thr190. The native ligand also forms several types of hydrophobic interactions with residues His-41; Met-49; Met-165; Leu-167; Pro-168; and Ala-191, while the rest were Van der Waals interactions with ten residues. The steroid sitostenone forms a hydrogen bond with the amino acids Gln-192. Ergosterol peroxide forms hydrogen bonds with Thr-26 and Gly-143. Sitostenone forms hydrophobic interactions with six amino acid residues Leu-27; His-41; Met-49; Cys-145; His-163; and Met-165, as well as Van der Waals interactions with 13 other amino acid residues. Ergosterol peroxide compounds form hydrophobic interactions with five amino acid residues, specifically His-41; Met-49; Cys-145; Met-165; and Arg-188, and form Van der Waals interactions with ten other amino acid residues. Overall, the interaction on sitostenone is more similar to the interaction of native ligands with a similarity level of $82.6 \%$ compared to ergosterol peroxide with $56.52 \%$.

The interaction pattern shows that the hydrophobic group on the ligands influences the SARS-CoV-2 $\mathrm{M}^{\text {Pro }}$ receptor's affinity. This is what causes the steroid class compounds to give good affinity for this molecular docking simulation. This is also related to the native ligand structure, an inhibitor of SARS-CoV-2 $\mathrm{M}^{\text {Pro, }}$, which is composed of several non-polar peptide groups. In terms of three-dimensional interactions (Figure 3), ergosterol peroxide does not occupy the protein's surface as large as the native ligand. However, the functional groups on its compounds bind to a larger hydrophobic region in the protein surface (brown area), and one oxygen group can interact in the polar region (blue area). Simultaneously, sitostenone compounds form a similar orientation to the native ligand in occupying the surface of the receptor's binding pocket.

Table III. Amino acid interactions of native and test ligands

\begin{tabular}{ccc}
\hline \multicolumn{3}{c}{ Interaction residues } \\
\hline N3 inhibitor (native ligand) & Sitostenone & Ergosterol peroxide \\
\hline Thr-24 & - & - \\
Thr-25 & - & Thr-25 \\
Thr-26 & Thr-26 & Thr-26 \\
- & Leu-27 & Leu-27 \\
His-41 & His-41 & His-41 \\
Met-49 & Met-49 & Met-49 \\
- & - & Pro-52 \\
- & - & Tyr-54 \\
Phe-140 & - & - \\
Leu-141 & Leu-141 & - \\
Asn-142 & Asn-142 & Asn-142 \\
Gly-143 & Gly-143 & Gly-143 \\
Ser-144 & Ser-144 & - \\
Cys-145 & Cys-145 & Cys-145 \\
His-163 & His-163 & - \\
\hline
\end{tabular}




\begin{tabular}{ccc}
\hline His-164 & His-164 & His-164 \\
Met-165 & Met-165 & Met-165 \\
Glu-166 & Glu-166 & Glu-166 \\
Leu-167 & Leu-167 & - \\
Pro-168 & Pro-168 & - \\
Asp-187 & - & Asp-187 \\
Arg-188 & Arg-188 & Arg-188 \\
Gln-189 & Gln-189 & Gln-189 \\
Thr-190 & Thr-190 & - \\
Ala-191 & Ala-191 & - \\
Gln-192 & Gln-192 & - \\
\hline The similarity of interaction & 82.6 & 56.52 \\
with native ligand (\%) & 82.6 & \\
\hline
\end{tabular}

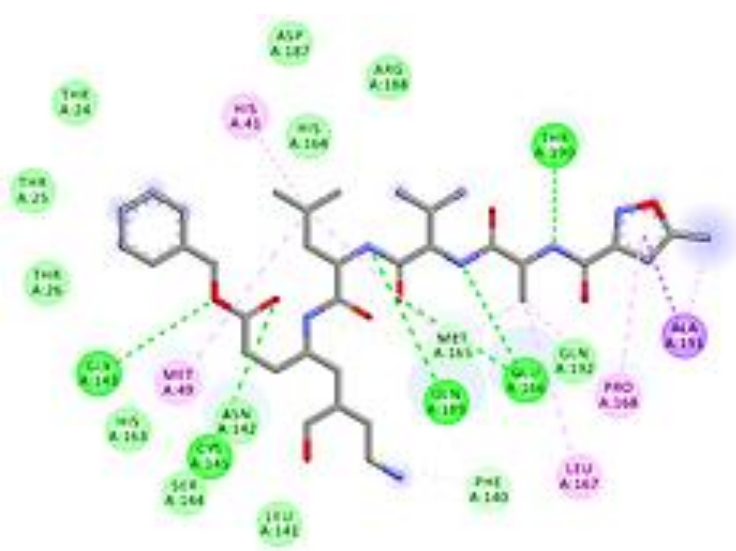

A
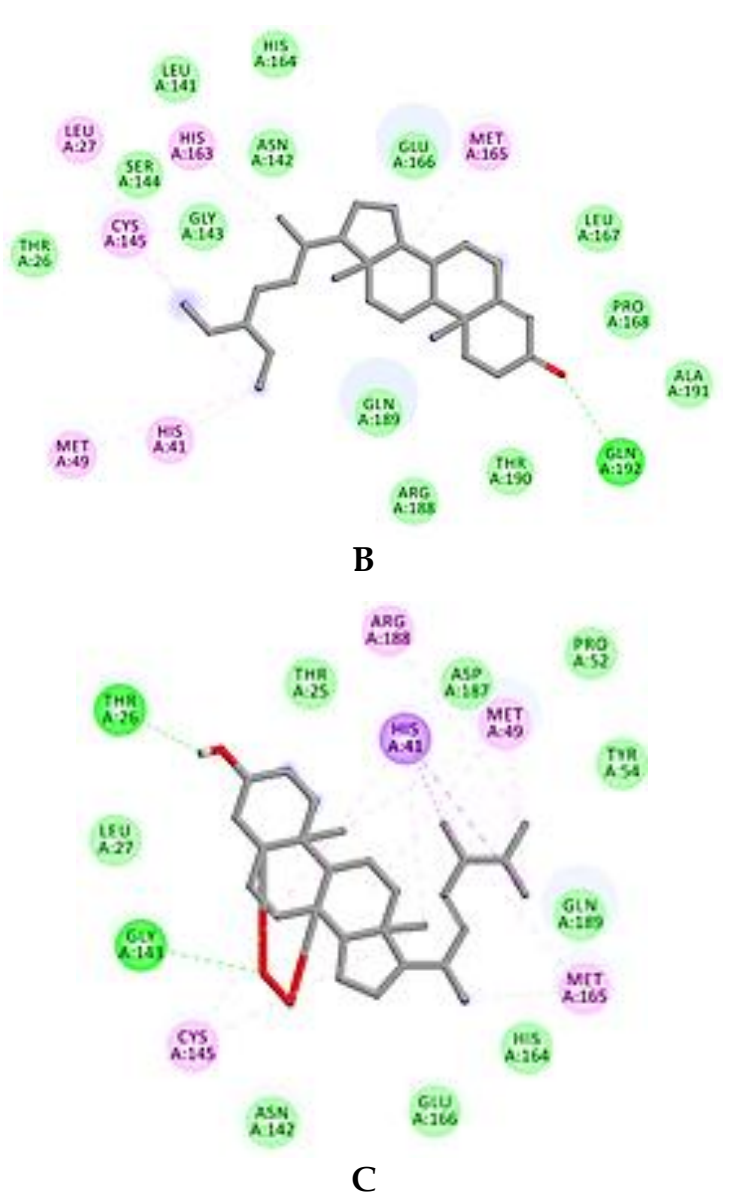

Figure 2. Two-dimensional interactions of native ligand (A), sitostenone (B), and ergosterol peroxide (C) to SARS-CoV-2 $\mathrm{M}^{\text {Pro }}$ receptor

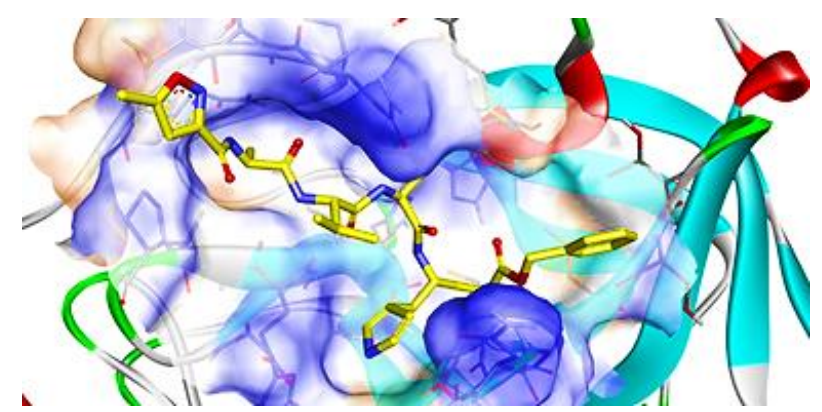

A

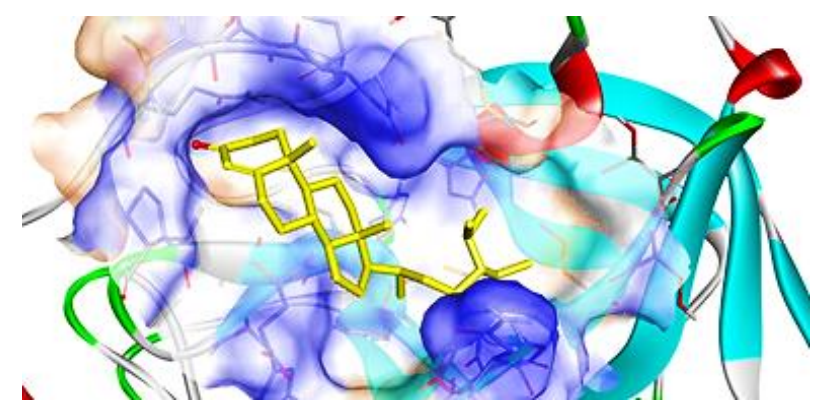

B

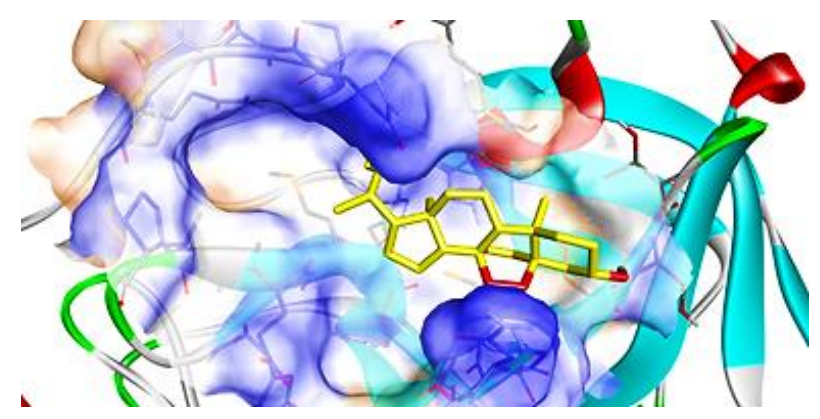

C

Figure 3. Three-dimensional interactions of native ligand (A), sitostenone (B), and ergosterol peroxide (C) to SARS-CoV-2 $\mathrm{M}^{\text {Pro }}$ receptor

\section{Prediction of Activity Spectra for Substances}

The PASS prediction was carried out on native ligand, ergosterol peroxide, and sitostenone compounds to see and compare their probability level as COVID-19 therapy (Table IV). The native ligand was predicted to have activity in severe acute respiratory syndrome treatment, 3C-like protease (Human coronavirus) inhibitor, protease inhibitor, and antiviral, with Pa value of $0.357 ; 0.358 ; 0.321$; and 0.312 , respectively. However, ergosterol peroxide and sitostenone were only predicted to have antiviral activity with a Pa value of 0.418 and 0.495 , respectively. 
Table IV. In Silico PASS Prediction results

\begin{tabular}{llcc}
\hline \multicolumn{1}{c}{ Ligands } & \multicolumn{1}{c}{ Activities prediction } & Pa & Pi \\
\hline Native & $\begin{array}{l}\text { Severe acute respiratory } \\
\text { syndrome treatment }\end{array}$ & 0.357 & 0.005 \\
& $\begin{array}{l}\text { 3C-like protease (Human } \\
\text { coronavirus) inhibitor }\end{array}$ & 0.358 & 0.006 \\
& Protease inhibitor & & \\
& Antiviral & 0.321 & 0.008 \\
Sitostenone & Antiviral & 0.312 & 0.033 \\
Ergosterol peroxide & Antiviral & 0.495 & 0.026 \\
& & 0.418 & 0.073 \\
\hline
\end{tabular}

\section{CONCLUSION}

Compounds in E. elatior (ergosterol peroxide and sitostenone) showed potential as inhibitor candidates for the SARS-CoV-2 $\mathrm{M}^{\text {Pro }}$ receptor. Although the PASS server's in silico prediction does not show specific activity against the receptor like native ligand, the bioactive compounds were predicted to have potential as antiviral. Moreover, from the molecular docking simulation, ergosterol peroxide and sitostenone showed better affinity against SARS-CoV-2 $\mathrm{M}^{\text {Pro }}$ compared to flavonoid groups and the native ligand.

\section{ACKNOWLEDGMENT}

We are grateful for the support of the Chancellor of Universitas Mandala Waluya and the Head of the Department of Pharmacy so the research can be carried out.

\section{REFERENCES}

Aanouz, I., Belhassan, A., El-Khatabi, K., Lakhlifi, T., ElLdrissi, M., \& Bouachrine, M. (2020). Moroccan Medicinal plants as inhibitors against SARSCoV-2 main protease: Computational investigations. Journal of Biomolecular Structure and Dynamics, Online ahead of print, 1-9. doi:10.1080/07391102.2020.1758790

Afendi, F.M., Okada, T., Yamazaki, M., Hirai-Morita, A., Nakamura, Y., Nakamura, K., Ikeda, S., Takahashi, H., Altaf-Ul-Amin, M., Darusman, L.K., Saito, K., \& Kanaya, S. (2012). KNApSAcK family databases: integrated metabolite-plant species databases for multifaceted plant research. Plant and Cell Physiology, 53(2), e1. doi:10.1093/pcp/pcr165

Bell, E.W. \& Zhang, Y. (2019). DockRMSD: an opensource tool for atom mapping and RMSD calculation of symmetric molecules through graph isomorphism. Journal of Cheminformatics, 11(1), 40. doi:10.1186/s13321-019-0362-7

Cherrak, S.A., Merzouk, H., \& Mokhtari-Soulimane, N. (2020). Potential bioactive glycosylated flavonoids as SARS-CoV-2 main protease inhibitors: A molecular docking and simulation studies. PLoS One, 15(10), e0240653. doi:10.1371/journal.pone.0240653

Dai, W., Zhang, B., Jiang, X.M., Su, H., Li, J., Zhao, Y., Xie, X., Jin, Z., Peng, J., Liu, F., Li, C., Li, Y., Bai, F., Wang, H., Cheng, X., Cen, X., Hu, S., Yang, X., Wang, J., Liu, X., Xiao, G., Jiang, H., Rao, Z., Zhang, L.K., Xu, Y., Yang, H., \& Liu, H. (2020). Structure-based design of antiviral drug candidates targeting the SARS-CoV-2 main protease. Science, 368(6497), 1331-1335. doi:10.1126/science.abb4489

Du, Q.S., Wang, S.Q., Zhu, Y., Wei, D.Q., Guo, H., Sirois, S., \& Chou, K.C. (2004). Polyprotein cleavage mechanism of SARS CoV Mpro and chemical modification of the octapeptide. Peptides, 25(11), 1857-1864. doi:10.1016/j.peptides.2004.06.018

Enmozhi, S., Raja, K., Sebastine, I., \& Joseph, J. (2020). Andrographolide as a potential inhibitor of SARS-CoV-2 main protease: an in silico approach. Journal of Biomolecular Structure and Dynamics, Online ahead of print, 1-7. doi:10.1080/07391102.2020.1760136

Fristiohady, A., Wahyuni, W., Malik, F., Yusuf, M.I., Salma, W.O., Hamsidi, R., Talebong, F., Yuliansyah, Y., Purnama, L.O.M.J., Saripuddin, S., \& Sahidin, S. (2020). Level of Cytokine Interleukin- 6 and Interleukin $1-\beta$ on Infectious Rat Model Treated with Etlingera elatior (Jack) R.M. Smith Fruit Extract as Immunomodulator. Borneo Journal of Pharmacy, 3(2), 52-57. doi:10.33084/bjop.v3i2.1318

Fristiohady, A., Zubaydah, W.O.S., Wahyuni, W., Mirda, M., Saripuddin, S., Andriani, R., Purnama, L.O.M.J., \& Sahidin, S. (2019). Immunomodulator Activity of Effervescent Granule of Wualae Fruit (Etlingera elatior 
(Jack) R.M. Smith) Based on Specific Phagocytic Activity. Borneo Journal of Pharmacy, 2(2), 35-40. doi:10.33084/bjop.v2i2.868

Ghosh, R., Chakraborty, A., Biswas, A., \& Chowdhuri, S. (2020). Potential therapeutic use of corticosteroids as SARS CoV-2 main protease inhibitors: a computational study. Journal of Biomolecular Structure and Dynamics, Online ahead of print, 1-14. doi:10.1080/07391102.2020.1835728

Hui, D.S., Azhar, E.I., Madani, T.A., Ntoumi, F., Kock, R., Dar, O., Ippolito, G., Mchugh, T.D., Memish, Z.A., Drosten, C., Zumla, A., \& Petersen, E. (2020). The continuing 2019-nCoV epidemic threat of novel coronaviruses to global health - The latest 2019 novel coronavirus outbreak in Wuhan, China. International Journal of Infectious Diseases, 91, 264-266. doi:10.1016/j.ijid.2020.01.009

Islam, M.T., Sarkar, C., El-Kersh, D.M., Jamaddar, S., Uddin, S.J., Shilpi, J.A., \& Mubarak, M.S. (2020). Natural products and their derivatives against coronavirus: A review of the nonclinical and pre-clinical data. Phytotherapy Research, 34(10), 2471-2492. doi:10.1002/ptr.6700

Jin, Z., Du, X., Xu, Y., Deng, Y., Liu, M., Zhao, Y., Zhang, B., Li, X., Zhang, L., Peng, C., Duan, Y., Yu, J., Wang, L., Yang, K., Liu, F., Jiang, R., Yang, X., You, T., Liu, X., Yang, X., Bai, F., Liu, H., Liu, X., Guddat, L.W., Xu, W., Xiao, G., Qin, C., Shi, Z., Jiang, H., Rao, Z., \& Yang, H. (2020). Structure of Mpro from SARS-CoV-2 and discovery of its inhibitors. Nature, 582, 289-293. doi:10.1038/s41586-020-2223-y

Joshi, T., Joshi, T., Sharma, P., Mathpal, S., Pundur, H., Bhatt, V., \& Chandra, S. (2020). In silico screening of natural compounds against COVID-19 by targeting Mpro and ACE2 using molecular docking. European Review for Medical and Pharmacological Sciences, 24(8), 4529-4536. doi:10.26355/eurrev_202004_21036

Mahmud, S., Uddin, M.A.R., Zaman, M., Sujon, K.M., Rahman, M.E., Shehab, M.N., Islam, A., Alom, M.W., Amin, A., Akash, A.S., \& Saleh, M.A. (2020). Molecular docking and dynamics study of natural compound for potential inhibition of main protease of SARS-CoV-2. Journal of Biomolecular Structure and Dynamics,
Online ahead of print, $1-9$. doi:10.1080/07391102.2020.1796808

Marwaha, A., Goel, R.K., \& Mahajan, M.P. (2007). PASSpredicted design, synthesis and biological evaluation of cyclic nitrones as nootropics. Bioorganic and Medicinal Chemistry Letters, 17(18), 5251-5255. doi:10.1016/j.bmcl.2007.06.071

Morris, G.M., Huey, R., Lindstrom, W., Sanner, M.F., Belew, R.K., Goodsell, D.S., \& Olson, A.J. (2009). AutoDock4 and AutoDockTools4: Automated docking with selective receptor flexibility. Journal of Computational Chemistry, 30(16), 2785-2791. doi:10.1002/jcc.21256

Mushtaq, S., Abbasi, B.H., Uzair, B., \& Abbasi, R. (2018). Natural products as reservoirs of novel therapeutic agents. EXCLI Journal, 17, 420-451. doi:10.17179/excli2018-1174

Nakamura, K., Shimura, N., Otabe, Y., Hirai-Morita, A., Nakamura, Y., Ono, N., Altaf-Ul-Amin, M., \& Kanaya, S. (2013). KNApSAcK-3D: a threedimensional structure database of plant metabolites. Plant and Cell Physiology, 54(2), e4. doi:10.1093/pcp/pcs186

Pan, S.Y., Zhou, S.F., Gao, S.H., Yu, Z.L., Zhang, S.F., Tang, M.K., Sun, J.N., Ma, D.L., Han, Y.F., Fong, W.F., \& Ko, K.M. (2013). New Perspectives on How to Discover Drugs from Herbal Medicines: CAM's Outstanding Contribution to Modern Therapeutics. Evidence-Based Complementary and Alternative Medicine, 2013, 627375. doi:10.1155/2013/627375

Prasanth, D.S.N.B.K., Murahari, M., Chandramohan, V., Panda, S.P., Atmakuri, L.R., \& Guntupalli, C. (2020). In silico identification of potential inhibitors from Cinnamon against main protease and spike glycoprotein of SARS CoV2. Journal of Biomolecular Structure and Dynamics, Online ahead of print, 1-15. doi:10.1080/07391102.2020.1779129

Pratama, M.R.F., Poerwono, H., \& Siswodihardjo, S. (2020). Molecular Docking of Novel 5-Obenzoylpinostrobin Derivatives as SARSCoV-2 Main Protease Inhibitors. Pharmaceutical Sciences, 26(Suppl 1), S63-S77. doi:10.34172/PS.2020.57 
Sahidin, S., Salsabila, S., Wahyuni, W., Adryan, F., \& Imran, I. (2019). Potensi Antibakteri Ekstrak Metanol dan Senyawa Aromatik dari Buah Wualae (Etlingera elatior). Jurnal Kimia Valensi, 5(1), 1-7. doi:10.15408/jkv.v5i1.8658

Sukardiman, S., Ervina, M., Pratama, M.R.F., Poerwono, H., \& Siswodihardjo, S. (2020). The coronavirus disease 2019 main protease inhibitor from Andrographis paniculata (Burm.f) Ness. Journal of Advanced Pharmaceutical Technology and Research, 11(4), 157-162. doi:10.4103/japtr.JAPTR_84_20

Suwannarach, N., Kumla, J., Sujarit, K., Pattananandecha, T., Saenjum, C., \& Lumyong, S. (2020). Natural Bioactive Compounds from Fungi as Potential Candidates for Protease Inhibitors and Immunomodulators to Apply for Coronaviruses. Molecules, 25(8), 1800. doi:10.3390/molecules25081800

Ulrich, S. \& Nitsche, C. (2020). The SARS-CoV-2 main protease as drug target. Bioorganic and Medicinal Chemistry Letters, 30(17), 127377. doi:10.1016/j.bmcl.2020.127377

Wahyuni, W., Malik, F., Ningsih, A., Zubaydah, W.O.S., \& Sahidin, S. (2018). Antimicrobial activities of ethanol extract of Wualae (Etlingera elatior (JACK) R.M. Smith). JPMS (Journal of Pharmaceutical and Medicinal Sciences). 3(1), 14 18.

World Health Organization. (2020). Coronavirus disease (COVID-19) Weekly Epidemiological Update and Weekly Operational Update: Weekly epidemiological update - 31 August 2020. https://www.who.int/publications/m/item /weekly-epidemiological-update--31-august2020

Wu, C., Liu, Y., Yang, Y., Zhang, P., Zhong, W., Wang, Y., Wang, Q., Xu, Y., Li, M., Li, X., Zheng, M., Chen, L., \& Li, H. (2020). Analysis of therapeutic targets for SARS-CoV-2 and discovery of potential drugs by computational methods. Acta Pharmaceutica Sinica B, 10(5), 766-788. doi:10.1016/j.apsb.2020.02.008

Zhu, L., George, S., Schmidt, M.F., Al-Gharabli, S.I., Rademann, J., \& Hilgenfeld, R. (2011). Peptide aldehyde inhibitors challenge the substrate specificity of the SARS-coronavirus main protease. Antiviral Research, 92(2), 204-212. doi:10.1016/j.antiviral.2011.08.001 